\title{
Carotenoid production by Rhodotorula rubra cultivated in sugarcane juice, molasses, and syrup
}

\author{
Produção de carotenoides por Rhodotorula rubra cultivada em caldo, melaço e xarope de cana-de-açúcar
}

\section{David BANZATTOํㅗㄹ Lidyane Aline de FREITA ${ }^{1 *}$, Márcia Justino Rossini MUTTON}

\begin{abstract}
The Rhodotorula rubra biomass and carotenoids production was evaluated in sugarcane juice, molasses, and syrup based media. The effects of media supplementation with urea- nitrogen or the commercial nutrient called Nitrofos KL was also verified. The experimental design used was a completely randomized factorial with 3 substrates (juice, molasses, and syrup) and three supplementations (control, urea, and Nitrofos KL). The results were submitted to variance analysis and Tukey test at $5 \%$ probability. The highest production of yeast dry mass was obtained with molasses media supplemented with urea or Nitrofos KL (15.09 and $14.87 \mathrm{~g} / \mathrm{L}$ respectively). The intracellular carotenoid production was high in the media without supplementation $(0.329 \mathrm{mg} / \mathrm{g})$. The best growth medium for the volumetric production was molasses $(2.74 \mathrm{mg} / \mathrm{L}), \mathrm{while}$ those supplemented with urea and Nitrofos KL produced 2.55 and $2.32 \mathrm{mg} / \mathrm{L}$, respectively. The major carotenoids produced were torulene, torularhodin, and $\beta$-carotene. The lowest carbohydrate consumption was observed in the sugarcane juice medium without supplementation, while the highest consumption was observed in the urea based supplementation medium.

Keywords: torulene; torularhodin; $\beta$-carotene; yeasts.
\end{abstract}

\section{Resumo}

A produção de biomassa e de carotenoides por Rhodotorula rubra foi estudada em meios à base de caldo, melaço e xarope de cana. Avaliou-se o efeito da suplementação dos meios com nitrogênio na forma de ureia ou do nutriente comercial Nitrofos KL. O delineamento experimental utilizado foi o inteiramente casualizado, no esquema fatorial $3 \times 3$, sendo um dos fatores o substrato (caldo, melaço e xarope) e o outro a suplementação (controle, ureia e Nitrofos KL). Os resultados foram submetidos à análise de variância e teste de Tukey a 5\% de probabilidade. As maiores produções de massa seca de levedura foram obtidas no meio à base de melaço suplementado com ureia ou Nitrofos KL (15,09 e $14,87 \mathrm{~g} / \mathrm{L}$, respectivamente). A produção de carotenoides intracelular foi elevada em todos os meios estudados sem suplementação $(0,329 \mathrm{mg} / \mathrm{g})$. Para a produção volumétrica, o melhor meio foi o melaço $(2,74 \mathrm{mg} / \mathrm{L})$, enquanto a suplementação com ureia e com Nitrofos KL produziu 2,55 e 2,32 mg/L, respectivamente. Os principais carotenoides produzidos foram toruleno, torularrodina e $\beta$-caroteno. No meio à base de caldo de cana sem suplementação, houve o menor consumo de carboidratos, enquanto que o meio com suplementação à base de ureia obteve o maior consumo.

Palavras-chave: toruleno; torularrodina; $\beta$-caroteno; levedura.

\section{Introduction}

Among the pigments, carotenoids are the most widely distributed in nature, with over 600 molecules already identified (FRASER; BRAMLEY, 2004). These molecules are often found in algae, filamentous fungi, yeasts, bacteria, and plants. However, animals are not able to synthesize them. Their main biological functions are the anti-carcinogenic and pro vitamin A properties, as well the effects against reactive oxygen species (YOUNG; LOWE, 2011). Because of their properties, there is a growing research demand for a more effective medium to produce these natural pigments, especially for food coloring and nutritional supplementation (DOWNHAM; COLLINS, 2000).

The main microbial sources able to synthetize these molecules are the yeast genus Phaffia and Rhodotorula, both characterized by high growth potential, high production of carotenoids, and the fact that they grow in low-cost culture media (AKSU; EREN, 2005; DOMÍNGUEZ-BOCANEGRA;
TORRES-MUÑOZ, 2004; TINOI; RAKARIYATHAM; DEMING, 2005).

Rhodotorula rubra shows high carotenoid growth rates and production in sugarcane juice (MAEDA, 2004). Sugarcane is widely spread in Brazil; the production reached 533.50 millions of tons/year (2011/2012 season) (UNIÃO..., 2012). The juice extracted from sugarcane is concentrated, from which the syrup, the molasses, and the final residue of sucrose are extracted. Due to their high carbohydrate concentration, the juice, syrup, and molasses are adequate substrates for fermentation. According to Ferrao and Garg (2012), macronutrient medium components play an important role in the biomass and product synthesis of any kind of microbial fermentation.

Carotenoids of biological origin can be economically competitive when compared to their synthetic analogs, optimizing the production chain (ERNST, 2002). 
Considering the low price and the wide availability of sugarcane-based media, this experiment was carried out aiming to maximize the carotenoids production by $R$. rubra using low cost (urea) supplementation available in the market (Nitrofos KL, Quimatec Produtos Químicos Ltda).

\section{Materials and methods}

\subsection{Microorganism}

The yeast strains used, R. rubra strain L18, were obtained from the Laboratory of Fermentation Processes, FCAV - UNESP, Jaboticabal, SP - Brazil. They were kept at $8{ }^{\circ} \mathrm{C}$ in tubes containing the culture medium YM agar (yeast extract $0.3 \%$, malt extract $0.3 \%$, peptone $0.5 \%$, dextrose $1 \%$, agar $2 \%$ ) and were kept alive by periodic transfer.

\subsection{Experiment design and statistical analysis}

A completely randomized design with a $3 \times 3$ factorial, 3 different culture media (juice, molasses and sugar cane syrup), 3 supplementations (control, urea and Nitrofos KL), and 3 replications was used. Data were submitted to an ANOVA, and the means were compared by Tukey test at $5 \%$ of probability.

\subsection{Culture media}

The culture media consisted of sugarcane juice, molasses, and syrup (Brix 19.5; 80.5 and 54.0 respectively) obtained from the Catanduva, SP-Brazil sugar mill. The molasses and syrup were two-fold diluted (w/v) and then hydrolyzed according to the Bhosale and Gadre (2001) method. The sugarcane juice was hydrolyzed without dilution.

The reducing sugars (RS) were quantified by the dinitrosalicylic acid (DNS) method (MILLER, 1959) presenting 140,170 , and $240 \mathrm{mg}$ of RS/g in the sugarcane juice, diluted syrup, and diluted molasses, respectively. From the hydrolyzed juice, the molasses, and the syrup, each culture medium was prepared with $40 \mathrm{~g}$ of RS/L. For the supplementations, $2 \mathrm{~g} / \mathrm{L}$ of urea and $0.5 \mathrm{~g}$ of Nitrofos $\mathrm{KL} / \mathrm{L}$ were used. The $\mathrm{pH}$ was adjusted to 5.5 , and the media were autoclaved at $121^{\circ} \mathrm{C}$ for 15 minutes.

\subsection{Mass production}

The yeast was collected from a storage tube and inoculated in an YM liquid medium.

The yeast was incubated for 72 hours at $30^{\circ} \mathrm{C}$ and then agitated at $200 \mathrm{rpm}$. After this period, the material was centrifuged, and the pellet was resuspended in $10 \mathrm{~mL}$ of sterile saline solution $(0.85 \%)$. The cellular concentration of this suspension was determined in a Neubauer chamber (LEE; ROBINSON; WONG, 1981) and inoculated in the culture media reaching an initial concentration of $10^{7}$ cells $/ \mathrm{mL}$. For mass growth and carotenoid production, $500 \mathrm{~mL}$ Erlenmeyer flasks containing $250 \mathrm{~mL}$ of adequately prepared culture medium, subjected to a $200 \mathrm{rpm}$ agitation and illuminated by 2 fluorescent light bulbs with $800 \mathrm{~lm}$ for 72 hours were used. Growth was monitored at 12-hour intervals using a spectrophotometer with optical density reading at $700 \mathrm{~nm}$.

\subsection{Carotenoids extraction, quantification, and identification}

Each erlenmeyer flask was centrifuged at 15,000 g per 10 minutes, and the pellet was resuspended with $10 \mathrm{~mL}$ of deionized water. The total residual reducing sugars (TRRS) of the supernatant were quantified with the DNS reagent. The frozen yeast mass was lyophilized in a Super Modulyo freezer dryer (Savant) for 24 hours. The yeast was frozen using liquid nitrogen.

The yeast dry mass was gravimetrically quantified and ground with celite and acetone at $6^{\circ} \mathrm{C}$ until full extraction of carotenoids (RODRIGUEZ-AMAYA, 1999). The extract was transferred to a separation funnel containing petroleum ether and three volumes of distilled water to remove the acetone. Anhydrous sodium sulfate was used to dry the non-polar phase, and then the pigments were concentrated on a rotating evaporator $\left(<35^{\circ} \mathrm{C}\right)$ to a volume of $6 \mathrm{~mL}$.

The total carotenoids were determined by spectrophotometry $(450 \mathrm{~nm})$ using the absorption coefficient $E_{1 \mathrm{~cm}}^{1 \%}=2500 \mathrm{in}$ petroleum ether, as suggested by Davies (1976). All procedures were performed under low-light conditions.

The greater amount of carotenoids were separated by thin layer chromatography (TLC), with silica gel plates (Silica Gel $\mathrm{G} 60,10 \times 20 \mathrm{~cm}, 0.25 \mathrm{~mm}$ of thickness), using both toluenepetroleum ether $(1: 9 \mathrm{v} / \mathrm{v})$ and toluene-acetone-methanol $(5: 20: 75 \mathrm{v} / \mathrm{v} / \mathrm{v})$ as mobile phases. Their absorption spectra were compared to those of previous studies (PERRIER; DUBREUCQ; GALZY, 1995; RODRIGUEZ-AMAYA, 1999) for identification.

\section{Results and discussion}

\subsection{Growth and biomass production}

During the first 24 hours after inoculation, the yeasts showed exponential growth and then remained stationary, as shown in Figure 1. This is the phase when there is the highest production of carotenoids due to a metabolic change from growth to pigment biosynthesis (COSTA et al., 1987); reason why incubation was kept for 72 hours.

For dry mass production, the $\mathrm{M} \times \mathrm{S}$ interaction was significant (Table 1), and Figure 2 results show that there was higher growth in the molasses-based media (15.09 and $14.87 \mathrm{~g} / \mathrm{L}$, respectively) However, the Urea and Nitrofos KL supplementations showed better results, except for the syrupbased medium, in which the supplementation with Nitrofos KL resulted in higher production of dry mass when compared to that of the control or urea. This is because the syrup is a medium poor in mineral salts (cofactors required for yeast growth), and the Nitrofos KL fulfills this deficiency since in addition to besides nitrogen, it contains phosphorus, magnesium, manganese, and zinc.

Faria (2008) using molasses supplemented with zinc, magnesium, and manganese found that the magnesium sulphate resulted in higher dry biomass production $(8.69 \mathrm{~g} / \mathrm{L})$, while the small value found was the treatment with zinc sulphate $(7.39 \mathrm{~g} / \mathrm{L})$ in $R$. rubra experiments. 


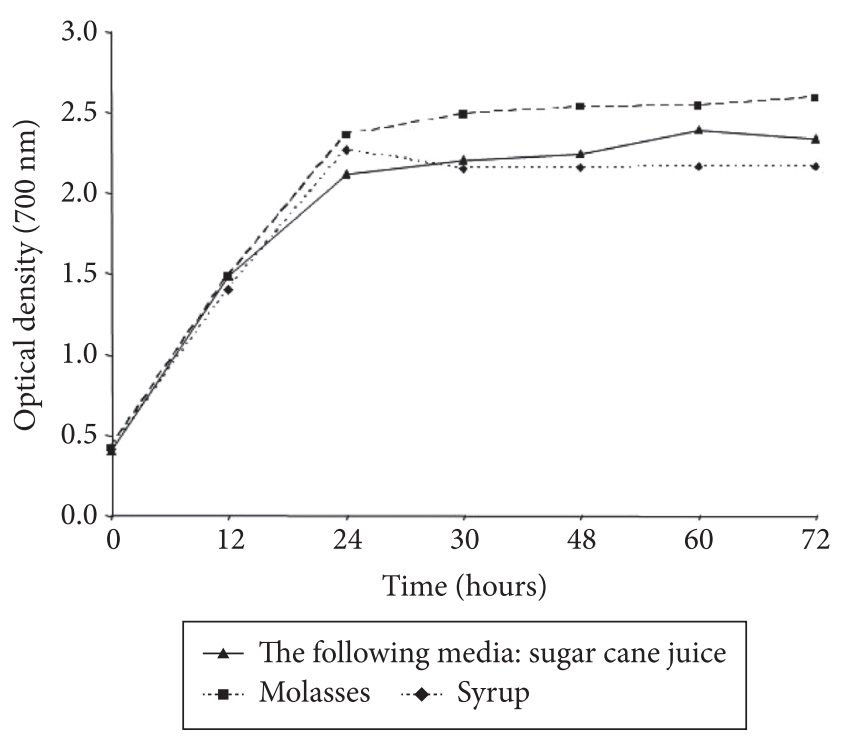

Figure 1. Growth curve of Rhodotorula rubra cultivated for 72 hours at $30^{\circ} \mathrm{C}$ and $200 \mathrm{rpm}$ in the following media: sugar cane juice, molasses and syrup.

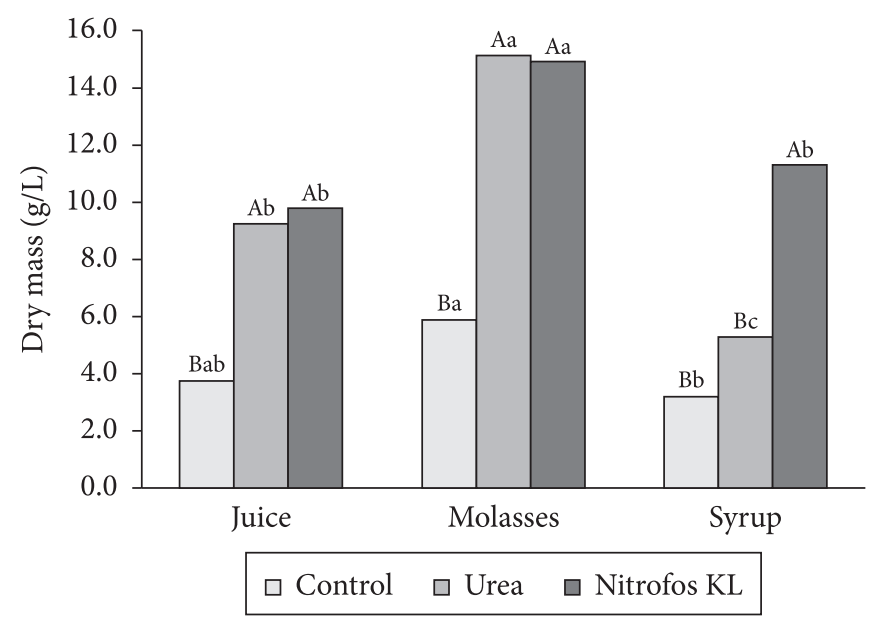

Figure 2. Rhodotorula rubra dry mass production in different media supplementations. Capital letters compare supplementation means, and lower case letters compare culture media means.

\subsection{Carotenoid production}

Both intracellular accumulation $(\mathrm{mg} / \mathrm{g})$ and volumetric carotenoid production $(\mathrm{mg} / \mathrm{L})$ were analyzed. The results (Figure 3) show that when there was no supplementation, there was a higher intracellular carotenoid accumulation $(0.329 \mathrm{mg} / \mathrm{g})$ when compared to that of Nitrofos KL supplementation. However, the results did not differ significantly from the supplementation with urea due to the culture medium nutrient limitation, resulting in carotenoid biosynthesis increase since it limits the growth of yeast (BOROWITZKA; BOROWITZKA, 1988).

With regard to the carotenoids volumetric production, the molasses-based medium had a higher carotenoids production, $2.74 \mathrm{mg} / \mathrm{L}$, while the urea and Nitrofos KL supplementation produced 2.55 and $2.32 \mathrm{mg} / \mathrm{L}$, respectively (Figure 4 ).

The molasses medium showed the highest volumetric carotenoid production (Figure 4), and since there was no variation in the medium composition in terms of RS concentration $(40 \mathrm{~g} / \mathrm{L})$, it can be assumed that this is results from the medium mineral composition (BUZZINI et al., 2005).

Supplementation plays a very important role in the volumetric carotenoid production since the addition of both urea and Nitrofos KL increased significantly the carotenoid production, as shown in Figure 5. Since this result is the opposite of that shown in Figure 3, it can be concluded that the supplementation decreased the intracellular carotenoid concentration, but it led to higher production of dry mass (Figure 2), and even with a lower carotenoid concentration, this final mass production of carotenoids per litter of medium ended up being higher.

\subsection{Carotenoid analysis and identification}

After separation by TLC, the main carotenoids were excised from the plates and resuspended in hexane. Absorption peaks were then compared to previous reports (Table 2), and the results showed that the main carotenoids produced were torulene, torularhodin, and $\beta$-carotene corroborating the findings of Maeda (2004) and Perrier, Dubreucq and Galzy (1995).

Table 1. Variance analysis of the characteristics evaluated in the production of carotenoids by Rhodotorula rubra culture grown at $30^{\circ} \mathrm{C}$ and $200 \mathrm{rpm}$ (rotay shaking) for 72 hours.

\begin{tabular}{|c|c|c|c|c|c|}
\hline \multirow{3}{*}{$\begin{array}{l}\text { Source of } \\
\text { variation }\end{array}$} & \multirow{3}{*}{ D.F. } & \multicolumn{4}{|c|}{ Mean squares } \\
\hline & & \multirow{2}{*}{ Dry mass } & \multicolumn{2}{|c|}{ Total carotenoids } & \multirow{2}{*}{ TRRS } \\
\hline & & & Intracellular $(\mathrm{mg} / \mathrm{g})$ & Volumetric $(\mathrm{g} / \mathrm{L})$ & \\
\hline Media (M) & 2 & $73.9040^{* *}$ & $0.0165^{\mathrm{ns}}$ & $2.6494^{* *}$ & $18.6137^{\star *}$ \\
\hline Supplementations (S) & 2 & $143.2862^{\star \star}$ & $0.0408^{\star *}$ & $2.5701^{\star \star}$ & $10.8075^{\star *}$ \\
\hline Interaction $\mathrm{M} \times \mathrm{S}$ & 4 & $13.2199^{* *}$ & $0.0147^{\mathrm{ns}}$ & $0.3115^{\mathrm{ns}}$ & $1.0505^{\mathrm{ns}}$ \\
\hline Residue & 18 & 1.6235 & 0.0061 & 0.1773 & 0.3681 \\
\hline C.V. (\%) & & 14.66 & 28.86 & 19.68 & 13.72 \\
\hline
\end{tabular}

${ }^{\mathrm{n}}$ Not significant $(\mathrm{P}>0.05) .{ }^{*}$ Significant $(\mathrm{P}<0.01)$. 


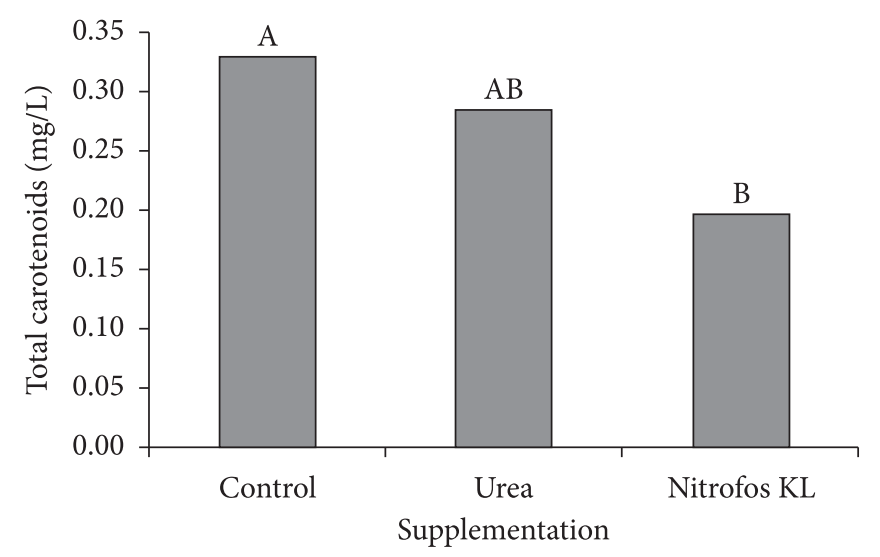

Figure 3. Rhodotorula rubra carotenoids intracellular production in different culture media supplementations. Data represent the average of the different culture media: sugarcane juice, syrup, and molasses.

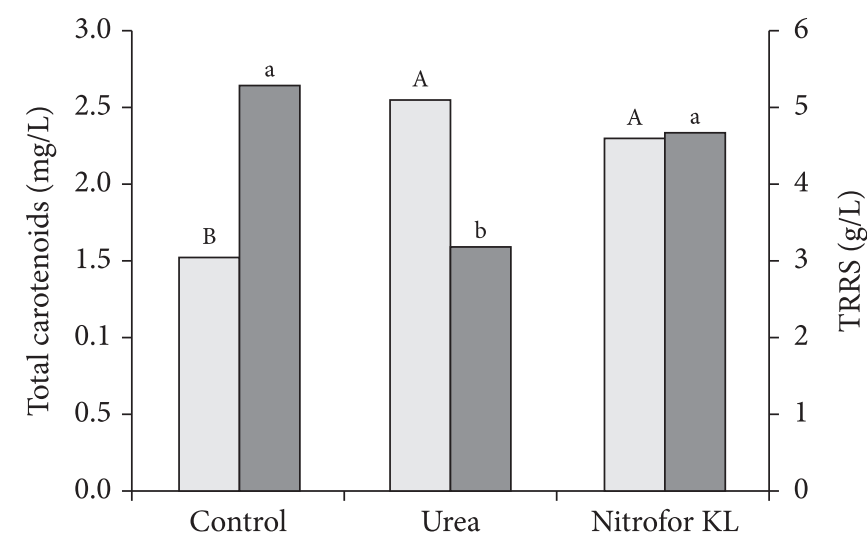

$\square$ Rhodotorula rubra volumetric carotenoid production $\square$ Total residual reducing sugars

Figure 5. Rhodotorula rubra volumetric carotenoid production and total residual reducing sugars in different supplementations. Data represent the average of the different media: sugarcane juice, syrup, and molasses.

\subsection{Total Residual Reducing Sugars}

After 72 hours of incubation, TRRS presenting higher amount of residual sugars in the broth $(6.05 \mathrm{~g} / \mathrm{L})$. These results may be explained by the fact that the broth showed the lowest production of carotenoids and dry mass, resulting in minimum use of the culture medium carbohydrate sources.

As for Figure 5, the urea supplemented medium had lower amounts of TRRS $(3.21 \mathrm{~g} / \mathrm{L})$, due to the low $\mathrm{C} / \mathrm{N}$ ratio, which stimulates yeasts to produce a higher amount of biomass consuming more carbohydrate from the medium (PARK et al., 2005).

\section{Conclusions}

The results show that the molasses-based medium is the most appropriate for carotenoid production due to its

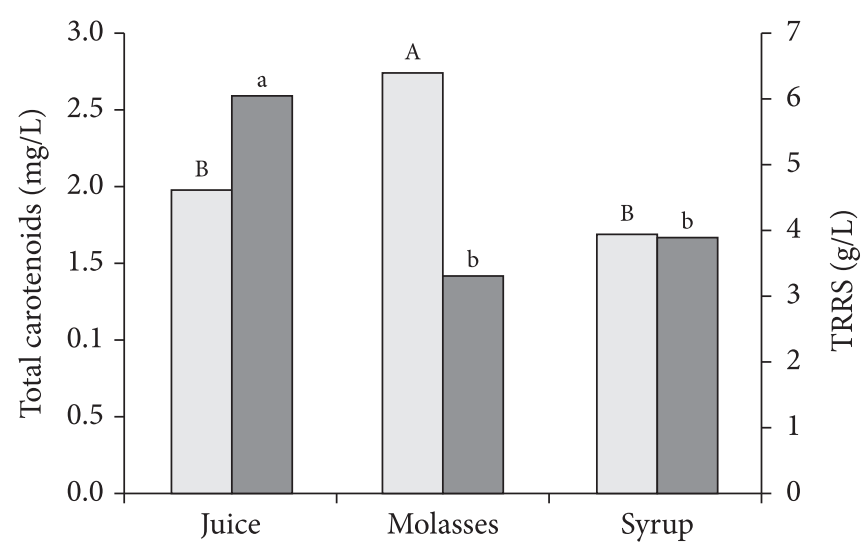

$\square$ Rhodotorula rubra volumetric carotenoid production

$\square$ Total residual reducing sugars

Figure 4. Rhodotorula rubra volumetric carotenoid production and total residual reducing sugars in different culture media. Data represent the average of the different supplementations: control, urea, and Nitrofos KL.

Table 2. Identification of main carotenoids produced by Rhodotorula rubra.

\begin{tabular}{|c|c|c|c|c|}
\hline \multirow{2}{*}{ Pigment } & \multicolumn{2}{|c|}{$\lambda_{\text {max }}(\mathrm{nm})$} & \multirow{2}{*}{ Identification } & \multirow{2}{*}{$\begin{array}{c}\text { Mobile } \\
\text { phase }\end{array}$} \\
\hline & Spectrum & Reference spectrum & & \\
\hline 1 & $458,483,516$ & $459,482,514^{a}$ & Torulene & II \\
\hline 2 & $456,492,527$ & $460,494,524^{\mathrm{a}}$ & Torularhodin & II \\
\hline 3 & $419,447,473$ & $(425), 450,477^{\mathrm{b}}$ & $\beta$-Carotene & I \\
\hline
\end{tabular}

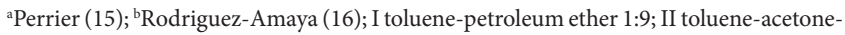
methanol 5:20:75.

higher volumetric carotenoid production and high dry mass production. The most appropriate supplementation for all analyzed media is urea since it leads to dry mass and carotenoid production increase.

\section{References}

AKSU, Z.; EREN, A. T. Carotenoids production by the yeast Rhodotorula mucilaginosa: Use of agricultural wastes as a carbon source. Process Biochemistry, v. 40, p. 2551-2557, 2005. http:// dx.doi.org/10.1016/j.procbio.2005.01.011

BHOSALE, P.; GADRE, R. V. $\beta$-Carotene production in sugarcane molasses by Rhodotorula glutinis mutant. Journal of Industrial Microbiology and Biotecnology, v. 26, p. 327-332, 2001. http:// dx.doi.org/10.1038/sj.jim.7000138

BOROWITZKA, M. A.; BOROWITZKA, L. J. Micro-algal biotechnology. FEBS Letters, v. 238, p. 222-223, 1988. http://dx.doi. org/10.1016/0014-5793(88)80268-0

BUZZINI, P. et al. Optimization of carotenoid production by Rhodotorula graminis DBVPG 7021 as a function of trace element concentration by mediums of response surface analysis. Enzyme and Microbial Technology, v. 36, p. 687-692, 2005. http://dx.doi. org/10.1016/j.enzmictec.2004.12.028 
COSTA, I. et al. Production of $\beta$-carotene by a Rhodotorula strain. Biotechnology Letters, v. 9, p. 373-375, 1987. http://dx.doi. org/10.1007/BF01025808

DAVIES, B. H. Carotenoids. In: GOODWIN, T. W. (Ed.). Chemistry and Biochemistry of plant pigments. New York: Academic Press, 1976. p. 38-165.

DOMÍNGUEZ-BOCANEGRA, A. R.; TORRES-MUÑOZ, J. A. Astaxanthin hyperproduction by Phaffia rhodozyma (now Xanthophyllomyces dendrorhous) with raw coconut milk as sole source of energy. Applied Microbiology and Biotechnology, v. 66, p. 249-252, 2004. PMid:15290135. http://dx.doi.org/10.1007/ s00253-004-1686-3

DOWNHAM, A.; COLLINS, P. Colouring our foods in the last and next millennium. International Journal of Food Science and Technology, v. 35, p. 5-22, 2000. http://dx.doi.org/10.1046/j.13652621.2000.00373.x

ERNST, H. Recent advances in industrial carotenoid synthesis. Pure and Applied Chemistry, v. 74, n. 11, p. 2213-2226, 2002. http:// dx.doi.org/10.1351/pac200274112213

FARIA, M. A. O. Produção de carotenóides por rhodotorula rubra em melaço suplementado com cátions bivalentes. 2008. Dissertação (Mestrado em Microbiologia Agropecuária)-Faculdade de Ciências Agrárias e Veterinárias, Universidade Estadual Paulista, Jaboticabal, 2008.

FERRAO, M.; GARG, S.; Shake flask optimization of $\beta$-carotene production in Rhodotorula graminis RC04. African Journal of Biotechnology, v. 11, n. 52, p. 11431-11437, 2012.

FRASER, P. D.; BRAMLEY, P. M. The biosynthesis and nutritional uses of carotenoids. Progress in Lipid Research, v. 43, n. 3, p. 228-265, 2004. PMid:15003396. http://dx.doi.org/10.1016/j. plipres.2003.10.002
LEE, S. S.; ROBINSON, F. M.; WONG, H. Y. Rapid determination of yeast viability. Biotechnology \& Bioengineering Symposium, n. $11,1981$.

MAEDA, F. Ánalise de carotenóides produzidos pela Rhodotorula rubra. 2004. 58 f. Dissertação (Mestrado em Microbiologia Agropecuária)-Faculdade de Ciências Agrárias e Veterinárias, Universidade Estadual Paulista, Jaboticabal, 2004.

MILLER, G. L. Use of dinitrosalicylic acid reagent for determination of reducing sugar. Analytical Chemistry, v. 31, p. 426-428, 1959. http://dx.doi.org/10.1021/ac60147a030

PARK, P. K. et al. Optimization of carotenoid production by Rhodotorula glutinis using statistical experimental design. World Journal of Microbiology \& Biotechnology, v. 21, p. 429-434, 2005. http://dx.doi.org/10.1007/s11274-004-1891-3

PERRIER, V.; DUBREUCQ, E.; GALZY, P. Fatty acid and carotenoid composition of Rhodotorula strains. Archives of Microbiology, v. 164, p. 173-179, 1995. PMid:7668929. http://dx.doi.org/10.1007/ BF02529968

RODRIGUEZ-AMAYA, D. B. A guide to carotenoids analysis in foods. Washington: International Life Science Institute, 1999. $64 \mathrm{p}$.

TINOI, J.; RAKARIYATHAM, N.; DEMING, R. L. Simplex optimization of carotenoid production by Rhodotorula glutinis using hydrolyzed mung bean waste flour as substrate. Process Biochemistry, v. 40, p. 2551-2557, 2005. http://dx.doi.org/10.1016/j.procbio.2004.11.005

UNIÃO DA INDÚSTRIA DE CANA-DE-AÇÚCAR - UNICA. Relatório safra 2011/2012. São Paulo: UNICA, 2012. Disponível em: <www.portalunica.com.br/referencia/estatistica.jsp $>$. Acesso em: 02 jun. 2012.

YOUNG, A. J.; LOWE, G. M. Antioxidant and prooxidant properties of carotenoids. Archives of Biochemistry and Biophysics, v. 385, n. 1, p. 20-27, 2001. PMid:11361018. http://dx.doi.org/10.1006/ abbi.2000.2149 